\title{
The Palestine Exploration Fund: A Society for the Accurate and Systematic Investigation of the Archaeology, Topography, Geology and Physical Georgaphy, Natural History, Manners and Customes of the Holy Land, for Biblical Illustration. Prospectus, 1866.
}

\section{George Grove}

To cite this article: George Grove (1865) The Palestine Exploration Fund: A Society for the Accurate and Systematic Investigation of the Archaeology, Topography, Geology and Physical Georgaphy, Natural History, Manners and Customes of the Holy Land, for Biblical Illustration. Prospectus, 1866., Palestine Exploration Quarterly, 1:sup1, 1-4, DOI: 10.1179/peq.1865.1-2.020

To link to this article: http://dx.doi.org/10.1179/peq.1865.1-2.020

册Published online: 17 Dec 2014.

Submit your article to this journal 주

Џ Article views: 6

Q View related articles ¿ 


\section{PALESTINE EXPLORATION FUND.}

A SOCIETY FOR THE ACCURATE AND SYSTEMATIC INVESTIGATION OF THE ARCH EOLOGY, TOPOGRAPHY, GEOLOGY AND PHYSICAL GEOGRAPHY, NATURAL HISTORY, MANNERS AND CUSTOMS OF THE HOLY LAND, FOR BIBLICAL ILLUSTRATION.

PATRON.

HER MAJESTY THE QUEEN. COMHITTEE.

ARCHBISHOP OF YORK.

DUKE OF ARGYLL.

DUKE OF DEYONSHIRE.

EarL of Carinarvon.

Eard of Derby.

Eare Rússeis..

HarL of Sbaftesbery.

EarL ZetLand.

Viscodnt Stratford de Redchiffe.

ViscodNT STRANGFord.

LORD DUFFERIN.

LORD HENRY LENNOX.

LoRd Henty J. M. D. Scott, M.P.

BISHOP OF LONDON.

BISHOP OF OXFORD.

Bishop of ELY.

Bishop OF Ripon.

The Speaker.

BaboN LiONel de Rothschild.

Syb John P. BoIlead, Bart., F.R.S. Sir Hentry Holland, Bart., F.R.S.

Sir S. Mor'ton Peto, Bart., M.P.

SAMUEL GURNEY, Esq., M.P.

Robert C. Hanbury, Esq., M.P.

A. H. LA YaRd, EgQ., M.P.

Walter Morrison, EsQ., M.P.

John Abel SMIth, EgQ., M.P.

Wirliam Tite, EsQ., M.P., F.R.S.

Dean of St. Paul's.

Dean of Westminster, F.R.S.

Dean of Christchurch.

Dean of Canterbury.

Sir HeNRy Rawlingon, K.C.B., F.R.S.

Str R. I. Murchison, K.C.B., F.R.S.

Profersor OWen, F.R.S.

Rev. Dr. Pusey.

Rev. H. M. Butler, D.D., Harrow.

REv. J. S. Howbon, D.D.
Rev. F. Temple, D.D., Rugby.

REv. C. J. VAUGHAN, D.D.

Canon Ernest Hawisins.

Rev. H. M. BIRCH.

Rev. G. G. Bradley, Marlborough

Rev. E. H. Plumptre.

Rev. Charles Pritchard, P.M.A.s.

hev. A. W. Thorold.

Rev. H. B. Tristram.

Rev. George Wilinamb.

Rev. Henky Aluon.

Rev. Samuel Martin.

Rev. Norman McLeod, D.D.

Rev. J. L. Porter, LI.D.

DR. H. W. AClaNd, F.R.S.

DR. Joseph D. HoOKER, F.R.S.

Dr. William Smith.

T. Farmer BaIly, Esq.

W. H. DIXoN, EsQ.

JaMer Fergusson, EsQ., F.R.S.

F. Waymouth Gibbs, Esq., C.B.

Crril Granam, Esq.

A. J. Beresford Hope, EsQ.

Brig.-General Lefroy.

Ambrobe L. P. De Liste, EsQ.

SAMUEL LlOYD, EgQ.

William Longman, EsQ.

JoHn MacGregor, EsQ.

Samuel Morley, EsQ.

John Morray, Esq.

Axtonio Panizzi, EbQ.

Henty Reeve, Eso.

G. Gilbert Scott, Esq., R.A.

W. SPOTTIgwoode, EsQ., F.R.S.

Willinam T'ipping, EsQ.

W. S. W. V $\mathbf{A D X}$, EsQ.

Georat Wood, ErQ., Bradford.

Treasurers : Robert C. Hanbery, Esq., M.P., and John Abel Smith, EsQ, M.P.

Bankers : Megses. Coutrs and Co., Strand.

The Union Bank of London, Princes Street, Mansion House.

Hon. Secretary: George Grove, Eso. 


\section{PROSPECTUS.}

NO country should be of so much interest to us as that in which the documents of our Faith were written, and the momentous events they describe enacted. At the same time no country more urgently requires illustration. The face of the landscape, the climate, the productions, the manners, dress, and modes of life of its inhabitants, differ in so many material respects from those of the western world, that without an accurate knowledge of them it is not too much to say the outward form and complexion of the events and much of the significance of the records must remain more or less obscure. Even to a casual traveller in the Holy Land the Bible becomes, in its form and therefore to some extent in its substance, a new book. Many an allusion which hitherto had no meaning, or had lain unnoticed, starts into prominence and throws a light over a whole passage. It is not to be expected that the modes of life and manners of the ancient Israelites will be revealed by any discovery of monuments in the same fulness that those of the Egyptians and Assyrians have been. But still, information of value cannot fail to be obtained in the process. Much would be gained by obtaining an accurate map of the country; by settling disputed points of topography; by identifying ancient towns of Holy Writ with the modern villages which are their successors; by bringing to light the remains of so many races and generations which must lie concealed under the accumulation of rubbish and ruins on which those villages stand; by ascertaining the course of the ancient roads; by the discovery of coins, inscriptions, and other relics-in short, by doing at leisure and systematically that which has hitherto been entirely neglected, or done only in a fragmentary manner by the occasional unassisted efforts of hurried and inexperienced travellers. Who can doubt that if the same intelligence, zeal, knowledge, and outlay were applied to the exploration of Palestine, that have recently been brought to bear on Halicarnassus, Carthage, Cyrene, places without a single sacred association and with little bearing on the Bible, the result would be a great accession to our knowledge of the successive inhabitants of Syria-Canaanite, Israelite, Roman?

Hitherto the opportunity for such systematic research has been wanting. It appears now to have arrived. The visit of H.R.H. the Prince of Wales to the Mosque at Hebron has broken down the bar which for centuries obstructed the entrance of Christians to that most venerable of the sanctuaries of Palestice; and may be said to have thrown open the whole of Syria to Christian research.

The survey of Jerusalem at present in progress under the direction of Captain Wilson, R,E.- a survey supported by the private liberality of a single personhas shown how much may be done with tact, temper, and opportunity, without arousing the opposition of the authorities or inhabitants. Recent letters of Sir H. James and others in the 'Times' have borne testimony to the remarkable fitness of Captain Wilson for such undertakings, and have pointed out other places where explorations might be advantageously carried on.

It is therefore proposed to raise a fund to be applied to the purposes of investigating the Holy Land by employing competent persons to examine the following points :

1. The Archoology.-Jerusalem alone would furnish an ample field in this department. What is above ground will be accurately known when the present survey is completed; but below the surface hardly anything has yet been dis. covered. The Tombs of the Kings on Mount Zion-the course of the Tyropoon Valley-the real extent of the Temple enclosure-the site of the Tower of 
Antonia-of the Palace of Herod-of Ophel-of the Pool of Bethesda-the position of the towers of Hippicus and Psephinus-the spring and conduit of Hezekiah-are all awaiting excavation; and it is not too much to anticipate that every foot in depth of the "sixty feet of rubbish" on which the city stands, will yield interesting and important materials for the Archaologist or the Numismatist.

Beyond the Holy City the country is full of sites which cannot fail amply to repay examination. Of these a few only may be enumerated :-Mount Gerizim, possibly the Moriah of Abraham's sacrifice, certainly the Holy P.lace of the Samaritans, containing the stones which they allege to have been brought up by Israel from the bed of the Jordan-the Valley of Shechem, the earliest settlement of Jacob in the Holy Land, with his Well and the 'lomb of Joseph-Samaria, with the traditional tombs of John the Baptist and others, and with the extensive remains of Herod's edifices-the splendid Roman cities along the coast, Crsarea of Herod and St. Panl-Antipatris-the once-renowned harbours of Jamnia and Gaza-the mounds and other remains of Jiljilieh, probably the Gilgal which contained the Great College of Prophets in the days of Elijali and Elisha-the Fortress and Yalace of Herod at Jebel Fureidis-the Tombs (probably those of Joshua) at Tibneh-the mounds at Jericho-the numerous remains in the Valley of the Jordan-Bethshean, one of the most ancient cities of Palestine, with remarkable remains of Roman, and probably still earlier, date-Jezreel, the capital of Ahab and Jezebel-the Assyrian mound, called Tell es Salhiyeh, near Damascus, \&c. \&c.

2. Manners and Customs.-A work is urgently required which shall do for the Holy Land what Mr. Lane's 'Modern Egyptians' has done for Egyptdescribe in a systematic and exhaustive order with clear and exact minuteness the manners, habits, rites, and language of the present inhabitants, with engravings intended like his "not to embellish the pages, but to explain the text." Many of the ancient and peculiar customs of Palestine are fast vanishing before the increasing tide of Western manners, and in a short time the exact meaning of many things which find their correspondences in the Bible will have perished. There are frequent references to these things in the books of travellers, and they have recently formed the subject of more than one entire work; but nothing sufficiently accurate or sytematic has been done. It can only be accomplished by the lengthened residence of a thoroughly competent person.

3. Topography. -0 the coast-line of Palestine we now possess an accurate map in the recent Admiralty Charts. What is wanted is a survey which when we advance inland should give the position of the principal points throughout the country with equal accuracy. If these were fixed, the intermediate spots and the smaller places could be filled in with comparative ease and certainty. In connexion with the topography is the accurate ascertainment of the levels of the various points. The elevation of Jerusalem and the depression of the Dead Sea are already provided for by the liberality of the Royal Society and the Royal Geographical Society; ${ }^{*}$ but the level of the Sea of Galilee (on which depends our knowledge of the true fall of the Jordan) is still uncertain within no less than 300 feet-as are other spots of almost"equal moment.

The course of the ancient roads, and their coincidence with the modern tracks, has never been examined with the attention it deserves, considering its importance in the investigation of the history.

The principle on which the modern territorial boundaries are drawn, and the towns aud villages allotteil between one district and another, would probably

* See Sir Henry James's letter to the 'Times,' Jan. 28, 1865. 
throw light on the course of the boundaries between the tribes and the distribution of the villages, which form the most puzzling point in the otherwise clear: specifications of the Book of Joshua.

4. Aeology.-Of this we are in ignorance of almost every detail. The valley of the Jordan and basin of the Dead Sea is geologically one of the most remarkable spots on the earth's surface. 'To use the words of Sir Roderick Murchison, "it is the key to the whole of the geology' of the district." Its Biblical interest is equally great. To name but one point. The decision of the question whether any volcanic changes have occurred round the margin of the lake within the historical period, may throw a new aspect over the whole narrative of the destruction of Sodom and Gomorrah.

5. Natural Sciences-Botany, Zoology, Meteorology.-These are at present but very imperfectly known, while the recent investigations of Mr. Tristram, limited as they necessarily were, show that researches are likely to furnish results of no common scientific interest. Naturalist after Naturalist will devote himself for years to the forests of South America, or the rivers of Africa. Why should we not have some of the same energy and ability applied to the correct description of the lilies and cedars, the lions, eagles, foxes, and ravens of the Holy Land?

It will perhaps be said that many of the points above enumerated have been already examined-that Robinson, Stanley, Rosen, and others have done much in the department of topography - that Hooker, and more recently Tristram, hape reported on the Botany-that Roth and Tristram have brought home shells, fish, birds, and eggs-that the researches of $M$. Lartet on the geology of the Dead Sea, and those of the Duc de Luynes, De Voguie, and De Saulcy on archæology, are on the eve of publication. This is true; but without intending to detract from the usefulness or the credit of the labours of these eminent men, it is sufficient to observe that their researches have been partial and isolated, and their results in too many cases discrepant with each other. What is now proposed is an expedition composed of thoroughly competent persons in each branch of research, with perfect command of funds and time, and with all possible appliances and facilities, who should produce a report on Palestine which might be accepted by all parties as a trustworthy and thoroughly satisfactory document.

It is hoped that an arrangement may be made by which Captain Wilson will be able to remain for a few months in the country after he has completed the survey of Jerusalem and the levelling between the Mediterranean and the Dead Sea ; and it will not be difficult to find competent persons to undertake the other departments named above. The annual cost of each investigator may be taken roughly at $800 l$. (including both remuneration and expenses).

Her Majegty The Queen has been graciously pleased to become the Patron of the Association, and to contribute to its funds.

The British Agrociation for tee Advancement of Science, at its recent Meeting at Birmingham, signified its approval of the undertaking, and its sense of the importance and feasibility of the investigation, by voting $100 l$. in its aid.

Subscriptions are received by the Bankers of the Association, Messrs. CotTrs and Co., Strand; and the Union Bank of London, Princes Street, Mansion House, and by the Hovorary Secretary.

$$
\text { By order of the Committee, }
$$

Syilenham, June 22, 1866.

Gronat Grove, Blon. Secretury. 